Article

\title{
Interdisciplinary Class Observation in Higher Education: Lessons Learned from the Professional Development Experience of Four Teachers
}

\author{
Joana P. Miranda ${ }^{1, *(\mathbb{D}, \text { Mariana Batista }}{ }^{2}$, Cristina Duarte ${ }^{3}$ and Tatiana Sanches ${ }^{4}$ (D) \\ 1 Research Institute for Medicines (iMed.ULisboa), Faculty of Pharmaceutical Sciences, Universidade de Lisboa, \\ 1649-003 Lisbon, Portugal \\ 2 Centro de Investigação Interdisciplinar em Sanidade Animal (CIISA), Faculdade de Medicina Veterinária, \\ Universidade Lusófona de Humanidades e Tecnologias, 1749-024 Lisbon, Portugal; \\ mariana.r.batista@gmail.com \\ 3 Instituto Superior de Ciências Sociais e Políticas, Universidade Lisboa, 1700-663 Lisbon, Portugal; \\ cduarte@iscsp.ulisboa.pt \\ 4 UIDEF, Instituto de Educação, Universidade de Lisboa, 1649-013 Lisbon, Portugal; tsanches@fpie.ulisboa.pt \\ * Correspondence: jmiranda@ff.ulisboa.pt
}

Citation: Miranda, J.P.; Batista, M.; Duarte, C.; Sanches, T.

Interdisciplinary Class Observation in Higher Education: Lessons Learned from the Professional Development Experience of Four Teachers. Educ. Sci. 2021, 11, 706. https://doi.org/ educsci11110706

Academic Editors: Hosam Al-Samarraie and Jianpeng Guo

Received: 30 August 2021

Accepted: 28 October 2021

Published: 3 November 2021

Publisher's Note: MDPI stays neutral with regard to jurisdictional claims in published maps and institutional affiliations.

Copyright: (c) 2021 by the authors Licensee MDPI, Basel, Switzerland. This article is an open access article distributed under the terms and conditions of the Creative Commons Attribution (CC BY) license (https:/ / creativecommons.org/licenses/by/ $4.0 /)$.

\begin{abstract}
Peer observation of teaching has been adopted as a method to improve the quality of teaching. It involves observers providing descriptive feedback to their peers on learning and teaching practices. However, although extensively described in the literature in the education field, its use as a tool for development beyond teaching skills has not been explored deeply, nor the best practices described. Therefore, the objective of this study was to compare quantitative with qualitative peer observation, as well as to investigate the role of interdisciplinarity in the observation process. The present study results from experimental observation work carried out by four professors of higher education. Veterinary science, social work, pharmaceutical sciences, and education, the disciplinary areas of origin of the teachers, were the ecosystems in which the initial observation techniques were explored and applied, and the intention was to share good practices and pedagogical improvements through peer support. This study reports the experience of building an observation grid and its application, as well as the lessons learned during the observation experience. The aim was to evaluate whether the constructive criticism was focused on the pedagogical practices rather than on the content, which can be useful in understanding if the learning objectives are being attained, from the teacher's point of view. As such, we employed and assessed peer observation as a constructive, developmental process for higher education teachers from different fields of knowledge. The study concludes that feedback by peers is essential for the development of professional practice in higher education teaching, with the experience of qualitative observation being a fundamental path for teacher self-reflection in the search for their own authenticity. It further supports the notion that interdisciplinary differences, methodologies, styles, contexts, and practices can be used in a constructive way to improve course content and delivery, and, ultimately, to reinforce good teaching.
\end{abstract}

Keywords: observation; pedagogical practices; interdisciplinarity; higher education; higher education teachers

\section{Introduction}

The quality of higher education and its premises have become increasingly relevant, especially since the beginning of the 21st century. The debate on its importance, as well as its social, economic, and political position, is ongoing. Furthermore, the impact of higher education on the training of citizens and the professionalization of its teachers regarding a general qualification in this area is increasing [1-4]. In fact, on 11 November 1997, UNESCO issued the Recommendation on the Statute of Teaching Staff in Higher Education, which is a founding declaration that seeks to guarantee quality principles in higher education 
systems [5]. It states that advances in higher education are based on the qualifications and knowledge of higher education teachers, as well as on their human, pedagogical and technical qualities, supported by academic freedom, professional responsibility, collegiality, and institutional autonomy [5]. As such, the investigation around the pedagogical training of teachers in higher education institutions has become not only understandable, but also fundamental [6] to the aim of responding to the current pedagogical challenges and curricular transformations (either suggested or imposed) with feasible and relevant changes, as well as with the mastery of pedagogical skills [7]. Subsequently, the training of higher education teachers emerged as an institutional concern [8,9], as was seen in different organizational modalities around the globe: postgraduate training, integrated or not in basic training; optional or compulsory training; training specifically focused on pedagogical aspects or evenly distributed by topics such as management, evaluation, and policies; frameworks of key competences for teachers; the granting of awards; and quality assurance and institutional certification strategies. These modalities are found in different countries and were developed to meet the growing need to operationalize professional teacher development [3-10]. Several explorations have been carried out to affirm pedagogy in higher education, with empirical studies emerging on the importance of professional teacher development [11-18]. As such, in addition to formal training, higher education teachers have participated in, and reflected on, non-formal training [19].

Emerging peer observation programs are among the most important programs for professional teacher development [20-23]. Observation consists of a data collection technique and assumes the main role in the experimental methodology. According to Estrela [24], naturalistic observation, when applied systematically to a field of pedagogy, allows for the collection of different information from that obtained through other techniques. This is because the intensity and detail of the "observed" attitude are concerns in the initial collection phase. Peer observation, in particular, is a collaborative model where peers come together to observe each other's practice, and where the meeting is not an end in itself, but the scenario where ideas can be expressed and a reflective dialogue is stimulated [25]. In Portugal, professional development methods, like peer observation, have also been adopted with documented success [26-29], as shown in a study with high school teachers [30], showing that an interdisciplinary model improves teachers' self-reflection as an effect of observing the process. It further supports teachers' community enhancement as they evolve with their peers.

There are two types of observation: quantitative observation, in which an observation grid is made; and qualitative observation, carried out through field notes. Despite the type of observation, all observation techniques consist of registering interaction units in a well-defined social situation based on what the observer sees and hears [31]. Thus, the observation practice plays a central role in any experimental methodology, making the observation process the first stage of more general scientific training. Consequently, it must be the primary step of a well-grounded pedagogical intervention [24]. Observation between peers, as a particular aspect of this research methodology, allows both the teacher who observes and the observed teacher increased perception regarding their practices, as it enables an exchange of information, questioning, suggestions or encouragement through a dialogue that is hoped is fruitful. This is, therefore, a beneficial practice for stimulating teacher professional development, allowing reflection and feedback $[20,21,32]$.

Nevertheless, observation is a complex and multifaceted process, while at the same time, selective and contextualized. We observe only from a point of view, just a frame of reference, a moment, a time, a place, as in a living photograph. However, what we observe has considerable reality. It includes what the other is, what we are, and what we want to see. In the words of Sanger [33] (p. 4): "doing observation for professional purposes is not as easy as it first appears. Far from being the first line of defense in the search for objectivity, it can be a leaky, permeable membrane. One which allows as much to issue from the observer as hits her wall of consciousness from the outside with that satisfying but deceptive thump of factuality. The key motif in much art and philosophy, not to mention 
psychology, is that of the observer seeking and discovering aspects of the self in the Other. By Other, I mean that which is outside, novel, strange or unknown".

Peer observation in higher education, in particular, benefits from contextual understanding, and the resulting professional teacher development can be explained by the cognitive influence that leads to choices supported by practices, as explained by the field of psychology [34]. This practice reveals the power of behavioral contagion, due to the human tendency to mimic behaviors deemed positive. Several studies have updated this topic, revealing that peer observation is a valid methodology, not only in several teaching cycles [35] but also, most importantly, in different disciplinary areas [36,37] and latitudes [38-40]. It has been reported that the success of the observational experience relies on elements such as session time, confidentiality, and clear and constructive feedback on what was observed [41], or even the reciprocity, inclusion, and operability of the observation [42]. Importantly, it should also be noted that this professional exercise should focus less on the observed and more on the observer's active self-development [43].

In line with other similar studies, the reflection on conceptions and practices consists as an opportunity for interdisciplinary experience, through peer observation [22,44]. Unlike multidisciplinarity, which is additive, interdisciplinarity is integrative, and this means that knowledge of different disciplines is contrasted and changed by integration [45]. Indeed, the plurality of technical and practical views enriches opinions and allows a discussion of the results with different and complementary contributions. This kind of integration or synthesis of knowledge is seen as the defining characteristic of interdisciplinarity [46], and, consequently, the ability to synthesize or integrate is considered as a beneficial learning outcome of interdisciplinary higher education. Additionally, observations in different disciplines may favor constructive and critical feedback, not only by helping lecturers to escape the constraints raised by a fear of prejudice of personal relationships, but also by reducing the focus on the contents being taught, as stated in previous experiences [29,47,48].

In this study, we aimed to compare quantitative with qualitative peer observation techniques and to perceive the contributions of the areas of veterinary science, social work, pharmaceutical sciences, and education, i.e., the role of interdisciplinarity in peer observation. Therefore, not only was reciprocal pair work considered, whereby two teachers pair up to study and observe each other as a rich form of professional development [18], but the observation methodology herein applied also included a new dimension, as it was enriched by its interdisciplinary character. As such, this work sought to promote a reflection on pedagogical practices by exploring the role of the professor as a subject capable of developing self and hetero-observation practices, thus improving their teaching and assessment methods. Ultimately, this study aimed for the development of the skills of observation of classes and a critical analysis of the different dimensions that contribute to the understanding of teaching-learning situations, namely in terms of the pedagogical relationship and communication in learning environments; selection, proposition, and development of teaching-learning strategies and activities; and support, assessment, and feedback strategies in the classroom.

\section{Materials and Methods}

The context for the present study arose as part of the professional practice development training of four higher education teachers within the frame of a postgraduate course on Pedagogy in Higher Education, from the University of Lisbon, Portugal, during the 2020/2021academic year, i.e., during the COVID-19 pandemic. It was carried out by four professors randomly selected to form a group for applying and developing peer observation methodologies. The four professors, female and 38-48 years of age, all taught in either public or private universities, with 3-10 years of teaching experience in the fields of veterinary science, social work, pharmaceutical sciences, or education.

The research design consisted of the peer observation of at least one of all the other participant teachers' lectures, i.e., each of the four teachers individually observed a lecture/class of the other three, as shown in Figure 1. The lectures consisted of online (via 
the Zoom platform) theoretical and practical classes from different cycles and years of study, with different ECTSs (European Credit Transfer System) and students, as referred to in Figure 2 and Table 1. The observation of all classes was done with the aid of both quantitative (Figure 2) and qualitative (Table 1) observational grids designed for this purpose. The observation was performed in two distinct and sequential moments: in the first moment, the observation was performed resorting to the quantitative grid; and in the second moment, the qualitative grid was used for the peer observation. In both moments, all four teachers observed and were observed by each other (Figure 1).

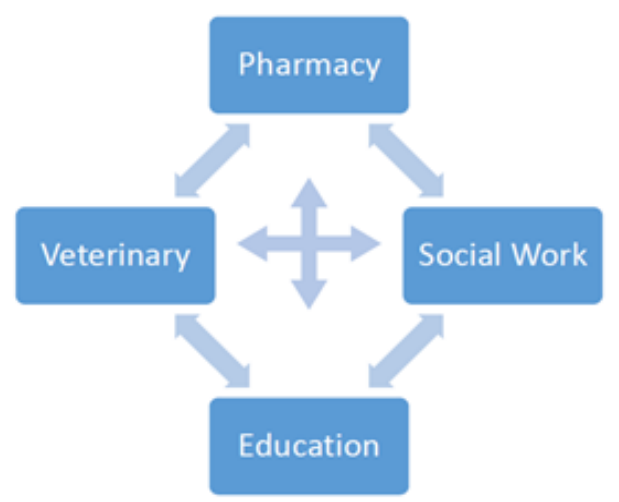

Figure 1. Schematic representation of the observation dynamics by peers.

According to Wragg [49], there are two traditions in observation-based studies. The quantitative, which involves the systematic measurement and careful control of conditions under which the observations take place, is based on counting and recording individual events. The qualitative style of observation tries to look behind and beneath the mere frequencies. Influenced by the work of cultural and social anthropologists, this style of observation searches for the significance, meaning, impact, and individual and collective interpretation of events, aligning different perceptions of what is happening in the classroom.

The design of the grids was inspired by the pedagogical triangle of Jean Houssaye, which considers the three pillars of the educational process, i.e., the teacher, the student, and the knowledge [50]. Therefore, covering the most important topics in the pedagogical space: teaching, learning, and training, as follows. In sum, besides the identification of the class (name of the teacher, disciplinary area, course year, and cycle), the grids requested the observation of parameters related to the teachers, their students, and class structure and organization (Figure 2). As such, regarding the teacher's proficiency, the observer was requested to analyze the teacher's communication skills, behavior engagement, time management skills, and their focus on the students. Regarding the students' behavior, the grid considered the students' engagement (whether their cameras were turned on or off, or whether they looked attentive), their active and constructive participation in class, their initiative to pose relevant questions (if any), and if they felt at ease within the classroom (in presential lectures). Finally, observers were also asked to analyze the curricular content of the class, focusing on whether the learning objectives were clearly stated, the logical structure of the class syllabus, the existence and pertinence of active learning strategies, and if the content of the class was sufficiently summarized at the end. 


\begin{tabular}{|l|c|c|}
\hline \multicolumn{3}{|c|}{ Identification data } \\
\hline Teacher name & Disciplinary field / CU & Year, Cycle of study \\
\hline & & \\
\hline
\end{tabular}

\begin{tabular}{|c|c|c|c|c|}
\hline \multicolumn{5}{|c|}{ Teacher performance-Performance, Commitment } \\
\hline & $\begin{array}{c}\text { Few } \\
\text { Evidence }\end{array}$ & $\begin{array}{c}\text { Some } \\
\text { Evidence }\end{array}$ & $\begin{array}{c}\text { Strong } \\
\text { Evidence }\end{array}$ & Comments \\
\hline \multicolumn{5}{|c|}{$\begin{array}{l}\text { Communication skills (accuracy, articulateness } \\
\text { and proficiency) }\end{array}$} \\
\hline \multicolumn{5}{|l|}{ Behaviour engagement } \\
\hline \multicolumn{5}{|l|}{ Time management } \\
\hline \multicolumn{5}{|l|}{ Focus on students } \\
\hline \multicolumn{5}{|c|}{ Students behaviour - Behaviour Engagement, Attitudes } \\
\hline & $\begin{array}{c}\text { Few } \\
\text { Evidence }\end{array}$ & $\begin{array}{c}\text { Some } \\
\text { Evidence }\end{array}$ & $\begin{array}{c}\text { Strong } \\
\text { Evidence }\end{array}$ & Comments \\
\hline \multicolumn{5}{|l|}{ Commitment (e.g. video on/off) } \\
\hline \multicolumn{5}{|c|}{ Participate actively in the discussion } \\
\hline \multicolumn{5}{|c|}{ Initiative (making relevant questions) } \\
\hline \multicolumn{5}{|c|}{$\begin{array}{l}\text { Environment adequacy (comfortable within the } \\
\text { class) }\end{array}$} \\
\hline \multicolumn{5}{|c|}{ Curricular Content - Organization, Structure } \\
\hline & $\begin{array}{c}\text { Few } \\
\text { Evidence }\end{array}$ & $\begin{array}{c}\text { Some } \\
\text { Evidence }\end{array}$ & $\begin{array}{c}\text { Strong } \\
\text { Evidence }\end{array}$ & Comments \\
\hline \multicolumn{5}{|l|}{ Learning objectives } \\
\hline \multicolumn{5}{|l|}{ Logical structure } \\
\hline \multicolumn{5}{|l|}{ Active learning strategies } \\
\hline Sum up at the end of the lecture & & & & \\
\hline
\end{tabular}

Figure 2. First observation grid used in quantitative peer observation.

\section{Results}

Observation constitutes a work tool that allows operation in a new pedagogical perspective. For this reason, it is assumed by many that the observation of educational situations remains one of the pillars of teacher training [24]. As such, this work consisted of a case study based on the application of the peer observational method for the improvement in the pedagogical skills of higher education teachers, considering all four teachers simultaneously in the observed and observer role. We sought to combine conceptual lines from higher education pedagogy, analyzing and reflecting on teacher development in the university context. Additionally, inter-peer observation from such diverse scientific areas is key to contributing distinct teaching methodologies, as well as personal and professional development, as each teacher allows themselves to reflect on the teaching process from a foreign perspective.

\subsection{From Drawing an Observation Grid to Peer Feedback}

To guarantee that all the observations were performed under the same circumstances, and therefore not biased by the nature of the different classes (in person, video-recorded, online, or video-recorded online classes), this study only included the observation of videorecorded online (Zoom) classes. Moreover, the same grids were used by the four teachers to guarantee that the same topics were observed. Two grids were designed, a quantitative grid and a qualitative grid (Figure 2 and Table 1). However, both grids evaluated the same parameters that were selected according to the pedagogical triangle of Jean Houssaye [50], which considers the three pillars of the educational process, i.e., the teacher, the student, 
and the knowledge. The model proposed by Houssaye promotes the observation of the pedagogical relationship as it views pedagogy as a process, that is, a stable, organized, and dynamic structure that is included in a situation. This pedagogical situation articulates three vertices - teacher, knowledge, and students-linked together through procedural dynamics, namely: the teaching process (relationship between knowledge and teacher), the training process (relationship between teacher and student), and the learning process (relationship between student and knowledge) [50].

The first observation exercise revealed that the presence of a quantitative scale (Figure 2) influenced the peers' observation, resulting mostly in a quantitative classification rather than in qualitative comments. The grid was designed for a quantitative assessment, although reserving specific spots for optional comments (Figure 2). The grid was relatively intuitive to fill in, highlighting the aspects that the observer needed to pay attention to. As such, it proved to be easy and quick to fill in. However, when analyzing the peers' observation comments, it became evident that, although straightforward to interpret, the quantitative grid lacked information, and revealed itself as an incomplete tool to truly assess peer teaching methods (supplementary data, Tables S1-S5). Moreover, most parameters were considered as revealing "strong evidence", which leaves little room for improvement. Indeed, an observation focusing solely on the quantification of the number of student-teacher interactions or on the number of times that each student intervenes does not completely reflect the whole teaching-learning process and its complex nature. Interestingly, perhaps influenced by its field of knowledge and sensitivity to pedagogical evaluations, the observations performed by the teacher from the education sciences had more frequent optional comments attached justifying the quantitative score and better enabling a self-reflective process by the observed. Therefore, these results suggested the need to rethink and design a new grid. The observation process should serve to reflect more on the educational situation and is more useful when focusing on the "hows" rather than the "whys". Feedback from peers must be formative, problematizing, and enhancing mutual learning, thus contributing to individual reflection, and enabling each teacher to further analyze their methodologies.

The second observation exercise was then based on a more qualitative grid (Table 1) that included more space for comments, demonstrating greater qualitative sensitivity, in line with the seminal work on observation in the teacher training context of Postic and Malaret [51].

As such, the transition from a quantitative to a qualitative observational model (Table 1) allowed the participants to focus on relevant aspects of the teaching-learning process, which serve as indicators of the teaching alliance in the classroom context, such as the identification of students' proactivity, time management within the class, coherence, clarity of speech, and the confidence with which the classroom space is used.

\subsection{Recasting Concepts and Practices}

To accommodate the above-mentioned reflections, a second observation exercise was set up using a reformulated grid (Table 1). This grid stimulated more accurate feedback and constructive criticism that could be beneficial, not only to the observed teacher, but also as an initiator of parallelisms in the observer/observed classes with consequent more robust integration of interdisciplinary pedagogical practices. The reformulation of this grid was, in itself, an important part of the self-reflection exercise of each teacher. The first inter-peer observation and its analysis were performed in naïve individuals. However, this first observation exercise enable to comprehend, mature concepts and expectations, thus allowing for a more effective and complete preparation for the second round of inter-peer observations. As mentioned above, as a direct result of the first analysis, the second grid included more space dedicated to the actual observation in which the "observer" learns and collaborates with the "observed", removing any quantitative or adjective components. Table 1 shows the results of all the observations produced during this work, using the upgraded observational qualitative grid. 
Table 1. Summary of the results obtained with the second peer observation exercise using a qualitative grid (Ed, education; Vt, veterinary; Ph, pharmaceutical sciences; SW, social work; ECTS, European Credit Transfer System).

\begin{tabular}{|c|c|c|}
\hline $\begin{array}{l}\text { Students Rating } \\
\text { (Posture, Attitude, } \\
\text { Comprehension, } \\
\text { Interaction) }\end{array}$ & $\begin{array}{c}\text { Peer Rating } \\
\text { (Posture, Assurance, } \\
\text { Awareness, Proficiency, } \\
\text { Organization) }\end{array}$ & $\begin{array}{c}\text { Curricula Content } \\
\text { (Suitability, Organization, } \\
\text { Structure) }\end{array}$ \\
\hline \multicolumn{3}{|c|}{ Social Work (SW) (1st Cycle/2nd Year/online theoretical lesson/5 ECTSs/29 students) } \\
\hline $\begin{array}{l}\text { - } \begin{array}{l}\text { Very few students } \\
\text { (about 1/5) with the } \\
\text { camera off and } \\
\text { muted } \\
\text { - }\end{array} \text { Seemingly focused } \\
\text { (Ed, Vt) } \\
\text { Some } \\
\text { student-teacher } \\
\text { interactions (Ed) } \\
\text { Interactive and } \\
\text { interrogative (Ph) } \\
\text { Comfortable with } \\
\text { Zoom technology } \\
\text { (Ed) } \\
\text { Participative and } \\
\text { comfortable within } \\
\text { the class (Ph) } \\
\text { Shy students with } \\
\text { few interactions, not } \\
\text { clear if comfortable } \\
\text { with Zoom } \\
\text { technology/online } \\
\text { classes (Vt) }\end{array}$ & $\begin{array}{ll}\text { - } & \text { Focus on students } \\
\text { - } & \text { learning } \\
\text { Reveals proficiency and } \\
\text { kindness } \\
\text { - } \quad \text { Use of pauses, question } \\
\text { making, and feedback } \\
\text { strategies to promote } \\
\text { teacher-student } \\
\text { interaction } \\
\text { Comfortable with Zoom } \\
\text { technology (Ed, Vt) } \\
\text { Fluent, clear, and } \\
\text { communication with } \\
\text { camera eye contact (as if it } \\
\text { was live) (Vt, Ph) }\end{array}$ & $\begin{array}{ll}\text { - } & \text { Use of examples as a } \\
\text { teaching strategy } \\
\text { - } \quad \text { Use of active learning } \\
\text { strategies (breakout } \\
\text { rooms) } \\
\text { - Concepts sequentially and } \\
\text { deeply approached } \\
\text { - Theoretical explanation, } \\
\text { using expositive teaching } \\
\text { method and resorting to } \\
\text { data show }(\mathrm{Vt})\end{array}$ \\
\hline \multicolumn{3}{|c|}{ Veterinary (Vt) (1st Cycle/2nd Year/regular presential practical lecture/6 ECTSs / 25 students) } \\
\hline $\begin{array}{l}\text { High level of } \\
\text { commitment in } \\
\text { learning with several } \\
\text { interactive moments } \\
\text { Informal } \\
\text { environment (Ed, } \\
\text { Ph) } \\
\text { The physical } \\
\text { distance between } \\
\text { students } \\
\text { compromises the } \\
\text { observation (SW) }\end{array}$ & 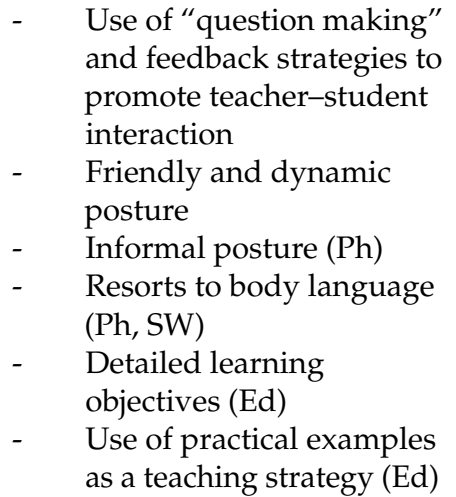 & 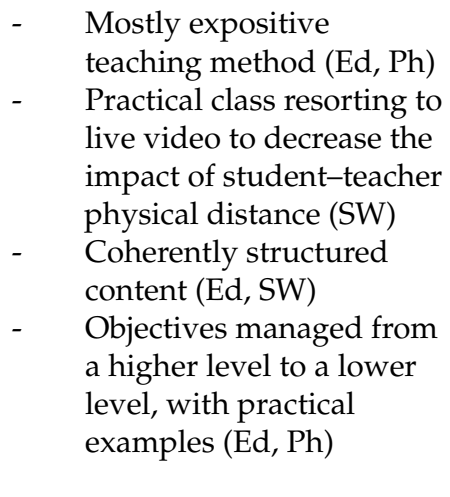 \\
\hline
\end{tabular}


Table 1. Cont.

\begin{tabular}{|c|c|c|c|}
\hline & $\begin{array}{l}\text { Students Rating } \\
\text { (Posture, Attitude, } \\
\text { Comprehension, } \\
\text { Interaction) }\end{array}$ & $\begin{array}{c}\text { Peer Rating } \\
\text { (Posture, Assurance, } \\
\text { Awareness, Proficiency, } \\
\text { Organization) }\end{array}$ & $\begin{array}{c}\text { Curricula Content } \\
\text { (Suitability, Organization, } \\
\text { Structure) }\end{array}$ \\
\hline \multicolumn{4}{|c|}{$\begin{array}{c}\text { Pharmaceutical sciences (Ph) (1st Cycle/2nd Year/online theoretical lesson/5 ECTSs/20 } \\
\text { students) }\end{array}$} \\
\hline - & $\begin{array}{l}\text { Comfortable with } \\
\text { Zoom technology } \\
\text { Most students with } \\
\text { the camera off and } \\
\text { muted } \\
\text { Answering } \\
\text { questions, revealing } \\
\text { commitment and } \\
\text { learning }\end{array}$ & $\begin{array}{ll}\text { - } & \text { Comfortable with Zoom } \\
\text { technology (Ed) } \\
\text { - } \\
\text { Focus on teaching and } \\
\text { students despite some } \\
\text { technical issues (Ed) } \\
\text { Reveals proficiency and } \\
\text { kindness (Ed) } \\
\text { Dynamic and friendly } \\
\text { communication (Ed) } \\
\text { Use of pauses, question } \\
\text { making, and feedback } \\
\text { strategies to promote } \\
\text { teacher-student } \\
\text { interaction } \\
\text { Reveals proficiency in the } \\
\text { field and commitment in } \\
\text { teaching (SW, Vt) } \\
\text { Clear and dynamic } \\
\text { communication to keep } \\
\text { the students focused: } \\
\text { different voice tones and } \\
\text { use of body language } \\
\text { enables emphasizing some } \\
\text { subjects (SW, Vt) } \\
\text { Tics in oral } \\
\text { communication (SW) }\end{array}$ & $\begin{array}{ll}\text { - } & \text { Learning objectives } \\
\text { presented (Ed, Vt) } \\
\text { - } \quad \text { Very well-planned } \\
\text { structure (Vt) } \\
\text { - Concepts clearly and well } \\
\text { organized and } \\
\text { approached } \\
\text { Expositive teaching } \\
\text { method (Ed, Vt) } \\
\text { Spiral approach } \\
\text { progression in teaching } \\
\text { (Ed) } \\
\text { The use of examples as a } \\
\text { teaching strategy further } \\
\text { promoting } \\
\text { student-teacher } \\
\text { interactions (Ed, SW) } \\
\text { The use of online pointer } \\
\text { helping communication } \\
\text { (SW) }\end{array}$ \\
\hline \multicolumn{4}{|c|}{ Education (Ed) (3rd Cycle/2nd Year/online theoretical lesson/5 ECTS/20 students) } \\
\hline - & $\begin{array}{l}\text { Comfortable with } \\
\text { Zoom technology } \\
\text { Committed and } \\
\text { active students: with } \\
\text { the camera on, } \\
\text { asking and } \\
\text { answering questions }\end{array}$ & 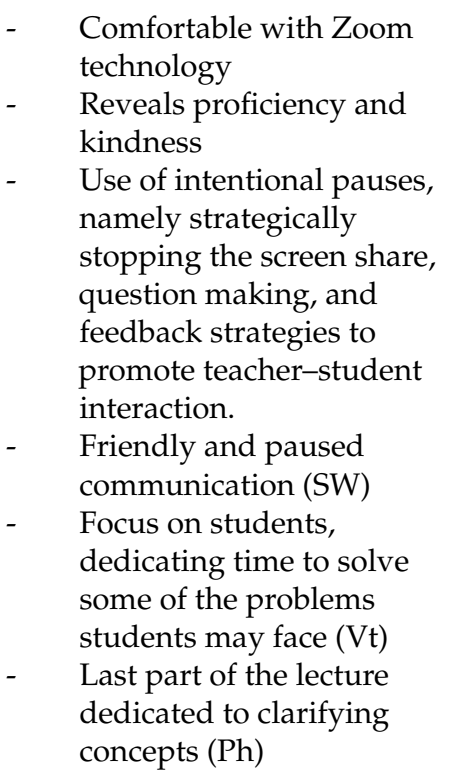 & $\begin{array}{ll}\text { - } & \text { Expositive teaching } \\
\text { method } \\
\text { - } & \text { Very well-planned } \\
\text { structure }(\mathrm{Ph}) \\
\text { - } \quad \text { Learning objectives } \\
\text { presented }(\mathrm{Ph}, \mathrm{Vt}) \\
\text { - } \quad \text { Concepts clearly and well } \\
\text { organized (SW, Ph) } \\
\text { - } \quad \text { Key questions for } \\
\text { validating the acquisition } \\
\text { of concepts }(\mathrm{Ph}) \\
\text { Great focus on } \\
\text { guaranteeing students' } \\
\text { learning }(\mathrm{Vt})\end{array}$ \\
\hline
\end{tabular}

The revised observational guide helped to focus the observation on key points of the class. Most comments were common to all observers, further supporting the notion that the interdisciplinary observation was indeed more focused on the attitudes of the observed 
rather than on the content of the classes. Furthermore, some observers pointed out different aspects of the same class, thus enriching the overall peer feedback of the observed teacher.

In addition, it is important to highlight that the distinct contexts, methods, and disciplinary practices of each field enriched the experience. Some aspects were only highlighted because the observers were from different fields and because, with the new observation grid, it became possible to include more reflexive comments. It is therefore highly beneficial to use the interdisciplinary observation process to learn about other pedagogical practices, through examples, to reflect and build new practices from an open and comprehensive observation [52].

\section{Discussion}

Given the current social context and the changes to higher education with online lectures becoming more prevalent, it is important to acquire new and improved tools to monitor and upgrade lectures, guaranteeing useful and constructive feedback. Thus, herein, we aimed to evaluate if constructive criticism focused on the pedagogical practices, rather than on content, can be useful in ascertaining if learning objectives are being attained, from the teacher's point of view. Constructive criticism provides a path to improvement through feedback, while highlighting the interplay of emotions and learning [53]. In the present study, constructive criticism has been used as a means to consider both competencies and deficiencies in the peer feedback emerging from the observation experience. Moreover, understanding how the observation technique of an impartial observer, from a different field of knowledge (i.e., without an in-depth knowledge of curricular content), could improve both the observer and the observed' s pedagogical skills is also desired. Indeed, a similar study [54] states that reviewed teachers gain confidence, anticipate improvement in teaching, and tend to discuss their teaching strategies more readily with peers.

According to Wragg [49], there are differences between participant and non-participant observers. In the author's words, insiders can sometimes find it difficult to detach themselves from prior knowledge, beliefs, commitments, and prejudices about a place they know very well and have seen every day for years (p. 15). Therefore, one of the advantages of this experience was that all the participating teachers observed unknown contexts, thus having a natural propensity for an emotional withdrawal and a rationalization of the observed events. This distance was also underlined by the fact that the observation was made through a video recording, due to the COVID-19 pandemic restrictions. On the other hand, the disadvantages included a loss of spatial assessment, as well as difficulty in obtaining a comprehensive notion of the felt environment, including a full perception of the students' expressions and reactions.

After the application of the second observational grid by the four teachers, it was possible to carry out a joint reflection to share the observations and their results. It was agreed that this experience emphasized the strengths and weaknesses of pedagogical practices that, without this exercise, would not have been revealed. The sensitivity acquired by the experience led to a subsequent self-reflection and consequent improvement in practices and strategies. This was the case, not only for aspects pointed out by peers, but also especially for those recognized by the subject himself, and which resulted from the mirror provided by the practical exercise. In a previous study [55], some disadvantages of peer observation were pointed out, emphasizing that when peers are known and from the same area, teachers tend not to consider peer feedback as very relevant. As a result, this mindset created widespread resistance and conflict towards the peer observation of teaching program initiatives, and was counterproductive to improving one's own pedagogy [55]. It is important to highlight that these observations, due to the interdisciplinary nature of the experience, gave a transforming meaning to the teaching practice, empowering the participants and potentially contributing to the quality of teaching. According to Carroll and O'Loughlin [56], successful peer observation should be voluntary, particularly for firsttime participants, involving peer self-selection and mutual trust and collaboration between 
the participants. Furthermore, as described previously, teaching peer observation was an effective activity that encouraged reflection regarding teaching approaches that further resulted in conceptual expansion and in changes concerning teaching strategies [57].

The most relevant statements regarding student observation (attitude, understanding, and interaction) demonstrated common aspects in the students' behavior, regardless of the subject area in which they were proficient, i.e., there are different learning styles, participation behavior, and interaction in the various subjects. Students can be more or less motivated, participative, or active, and need more or less direct support from the teacher, but students' learning results are interconnected with the quality of the teachers [4]. Thus, it is important to use different strategies (which different teachers use according to their own experience and personality) for pedagogical differentiation and the personalization of learning. Different exercises, the introduction of active methods, and attention to the difficulties of each student must be observed by each teacher, as well as specific stimuli to enhance the dynamics of the class. This can have a significant impact on the learning environment that may become more cooperative and participative. According to Bozkurt, awareness by the teachers arising from peer observation impacts their support of students' skill development, such as self-regulation, critical thinking, and decision-making [58].

As for the observation of the peer (posture, security, awareness, proficiency, and organization), it was possible to understand several issues that are more related to pedagogical style, but which can result when incorporated into pedagogical practices in different contexts. In effect, documenting teaching behavior with an observation instrument could support the observer and the observed lecturer by providing a common language regarding teaching behavior [59]. For example, a greater awareness of language and communication effectiveness allowed for a significant improvement between the first and second observations. In addition, the way in which each teacher dominated the space, intervened in the management of the classroom, or took breaks for student intervention were aspects that stood out in the observation and can easily be applied transversally. A previous study [60] showed that, for teachers not trained in pedagogical skills, the observation program was a good strategy to ascertain their needs. The main objective, outlined in this study, was for teachers to be able to improve pedagogical strategies, upskill and reskill their competencies, and be able to create a conducive and meaningful learning environment for the future generation.

Regarding the observation of the curriculum in action (adaptation, organization, and structure), the structuring of classes significantly improved when wrapping-up strategies were adopted at the beginning and end of sessions, as well as the introduction of practical exercises in theoretical classes or theorization in practical classes, leading to improved teaching strategies. The empowerment of students in understanding the curricular material from more immediate application exercises also proved to be an important strategy that can be used in different subject areas. Importantly, despite their foundation, all scientific areas seek students with a critical and interventionist attitude within their field of action. Contributions from each of the distinct areas have the potential to transform and broaden the participants' understanding, beyond the disciplinary content, enabling a broader discussion based on educational inquiry.

Finally, it is worth mentioning that, in line with the literature review [41-43], this observation experience proved to have a greater impact on the teachers playing the role of observer-in a strange environment and having the opportunity to absorb different pedagogical practices-rather than as the subject of observation, despite peer feedback. Nevertheless, a recent survey-based study that used a similar approach revealed that faculty members value the qualities of good teaching, agree that the peer review process should be required, and agree that peer reviewers should have several years of teaching experience [54]. These findings may provide clues to improve the peer observation experience.

In a recent testimony aired by the OECD Education and Skills Today channel [61], it was stated that the idea behind this is that good learning is not about copying and pasting solutions from other places, but about looking seriously and dispassionately at 
good practice in our own countries and elsewhere to become knowledgeable about what works in which contexts, and applying it consciously.

At the same time, and according to previous studies [56], to achieve the full value of peer observation, the key is that participants should provide full, impartial, and constructive criticism, as only focusing on the positive did not yield insights into how the teaching performance could be enhanced. Indeed, teacher observation is most beneficial when the lead teacher seeks out and invites a diverse group of peers who both share his or her desire to improve teaching practice and represent a wide range of backgrounds and experiences [62]. Therefore, the immersive experience proved to be a strategy that induced self-reflection, precisely due to the opportunity to contrast several pedagogical situations in a real environment. As stated in a recent study [4]: "when peer observation of teaching is incorporated into the practice and culture of the university and it is carried out in a mutually respectful and supportive way, it has the potential to facilitate a reflective change and teacher growth." This also means that peer feedback is a powerful tool that can be used to strengthen professional development and improve teaching practices [63], and which also reveals an improvement in trust in collaborative settings [64].

\section{Conclusions}

This work aimed to deepen the reflection on the role of the current pedagogical practices in higher education teaching and to raise awareness among teachers about their performance in order to improve it. The data gathered during the interdisciplinary observations were presented and discussed here. Moreover, this study showed that qualitative peer observation resulted in more constructive criticism, thus promoting teacher development. The fact that individuals from different disciplinary areas found coherence and a solid structure in all classes demonstrates the quality of the classes and constitutes a strong basis for improving them further. It showed that the interdisciplinary observation was indeed more focused on the attitudes of the observed rather than on the content of the classes. The different approaches to class planning and the student-faculty dynamics allowed the observers to see an "out-of-the-box" approach to their classes, thus revealing new paths for their own positive evolution. This was also a result of interdisciplinary peer observation.

Overall, interdisciplinary and qualitative peer observation has proven to be a path to mutual enrichment, not only because it recognizes that the strategies used by others can be transposed to our own fields, but also because it makes it easier to recognize our own weaknesses and strengths. It results in the opportunity to (de)construct and consolidate pedagogical methods and the possibility to reformulate them, as the peer perspective is an important strategy to help and motivate. Thus, interdisciplinary feedback is a fundamental way to facilitate self-reflection in higher education teachers in their search for authenticity, considering the differences in methodologies, styles, contexts, and practices. We conclude that interdisciplinary relationships, together with qualitative assessments based on peer observation, positively contribute to the teaching-learning process, adding to the empowerment of the participants and to a continuous improvement in their pedagogical practices.

Supplementary Materials: The following are available online at https://www.mdpi.com/article/10 .3390 /educsci11110706/s1, Table S1: Pharmacy (Ph), Social Work (SW) and Veterinary (Vt) teachers' feedback summary obtained during the Education teacher peer observation session, Table S2: Pharmacy (Ph), Education (Ed) and Veterinary (Vt) teachers' feedback summary obtained during the Social Work teacher peer observation session, Table S3: Pharmacy (Ph), Social Work (SW) and Education (Ed) teachers' feedback summary obtained during the Veterinary teacher peer observation session, Table S4: Social Work (SW), Veterinary (Vt) and Education (Ed) teachers' feedback summary obtained during the Pharmacy (Ph) teacher peer observation session, Table S5: Qualitative observation grid used in the second peer observation.

Author Contributions: Conceptualization, J.P.M., M.B., C.D. and T.S.; methodology, J.P.M., M.B., C.D. and T.S.; formal analysis, J.P.M. and C.D.; investigation, J.P.M., M.B., C.D. and T.S.; resources, J.P.M., M.B., C.D. and T.S.; data curation, J.P.M., M.B., C.D. and T.S.; writing—original draft preparation, 
T.S.; writing-review and editing, J.P.M. and M.B. All authors have read and agreed to the published version of the manuscript.

Funding: This research received no external funding.

Conflicts of Interest: The authors declare no conflict of interest.

\section{References}

1. Ambrósio, T. Conhecimento pedagógico e as competências formativas dos professores/investigadores universitários. In Educação e Desenvolvimento: Contributo para uma Mudança Reflexiva da Educação; Ambrósio, T., Ed.; FCT-UNL: Lisboa, Portugal, 2001; pp. 193-200.

2. Fry, H.; Ketteridge, S.; Marshall, E.S. A Handbook for Teaching and Learning in Higher Education: Enhancing Academic Practice; Kogan Page: London, UK, 1999.

3. Almeida, M.; Viana, J.; Sanches, T.; Paz, A.L. Tendências recentes da investigação internacional sobre Pedagogia do ensino superior: Uma revisão da literatura. Rev. Lusofona Educ. 2020, 45, 201-217.

4. Torres-Cajas, M.; Lara-Velarde, A.; Yépez-Oviedo, D.; Heredia-Arboleda, E. Teacher Coassessment Process in Higher Education. Atenea 2021, 26, 347-364.

5. ILO/UNESCO. The ILO/UNESCO Recommendation Concerning the Status of Teachers (1966) and the UNESCO Recommendation Concerning the Status of Higher-Education Teaching Personnel (1997) with a Revised Foreword and User's Guide; ILO/UNESCO: Paris, France, 2016.

6. Kuzhabekova, A.; Hendel, D.D.; Chapman, D.W. Mapping Global Research on International Higher Education. Res. High. Educ. 2015, 56, 861-882. [CrossRef]

7. Esteves, M. Modos de implicação dos professores na docência universitária. In Proceedings of the XI Congresso da Sociedade Portuguesa de Ciências da Educação, Guarda, Portugal, 30 June-2 July 2011.

8. Lewis, K.G. Pathways toward improving teaching and learning in higher education: International context and background. New Dir. Teach. Learn. 2010, 2010, 13-23. [CrossRef]

9. Sorcinelli, M.; Austin, A.; Eddy, P.; Beach, E.A. Creating the Future of Faculty Development: Learning from the Past, Understanding the Present; Anker Press: Bolton, MA, USA, 2006.

10. Aramburuzabala, P.; Hernández-Castilla, R.; Ángel-Uribe, I.C. Modelos y Tendencias de la Formación. Profr. Rev. Curric. Form. Profr. 2013, 17, 345-357.

11. de la Cruz Tomé, M.Á. Necesidad y objetivos de la formación pedagógica del profesor universitario. Rev. Educ. 2003, 331, 35-66.

12. Cunha, M.I. Impasses contemporâneos para a pedagogia universitária no Brasil. In Sentidos da Pedagogia no Ensino Superior; Leite, C., Ed.; CIIE: Porto, Portugal, 2010; pp. 63-74.

13. Davidson, M. Bones of contention: Using self and story in the quest to professionalize higher education teaching-An interdisciplinary approach. Teach. High. Educ. 2004, 9, 299-310. [CrossRef]

14. de Ketele, J.-M. La formación didáctica y pedagógica de los profesores universitarios: Luces y sombras. Rev. Educ. 2003, 331, 143-169.

15. Elton, L. Continuing Professional Development in Higher Education: The Role of the Scholarship of Teaching and Learning. Arts Humanit. High. Educ. 2009, 8, 247-258. [CrossRef]

16. Gibbs, G.; Coffey, M. The Impact of Training of University Teachers on their Teaching Skills, their Approach to Teaching and the Approach to Learning of their Students. Act. Learn. High. Educ. 2004, 5, 87-100. [CrossRef]

17. Zabalza, M. Innovación en la enseñanza universitaria. Context. Educ. Rev. Educ. 2004, 6, 113-136. [CrossRef]

18. Zabalza, M. Competencias Docentes del Profesorado Universitario: Calidad y Desarrollo Profesional; Narcea: Madrid, Spain, 2007.

19. Åkerlind, G.S. Growing and Developing as a University Teacher-Variation in Meaning. Stud. High. Educ. 2003, 28, 375-390. [CrossRef]

20. Bell, A.; Mladenovic, R. The benefits of peer observation of teaching for tutor development. High. Educ. 2008, 55, 735-752. [CrossRef]

21. Huston, T.; Weaver, C.L. Peer Coaching: Professional Development for Experienced Faculty. Innov. High. Educ. 2008, 33, 5-20. [CrossRef]

22. A Martin, G.; Double, J. Developing higher education teaching skills through peer observation and collaborative reflection. Innov. Educ. Teach. Int. 1998, 35, 161-170. [CrossRef]

23. Lygo-Baker, S.; Kokotailo, P.K.; Young, K.M. Developing Confidence in Uncertainty: Conflicting Roles of Trainees as They Become Educators in Veterinary and Human Medicine. J. Veter. Med. Educ. 2015, 42, 364-372. [CrossRef]

24. Estrela, A. Teoria e Prática de Observação de Classes: Uma Estratégia de Formação de Professores; Porto Editora: Porto, Portugal, 1994.

25. O'Leary, M.; Price, E.D. Peer observation as a springboard for teacher learning. In Reclaiming Lesson Observation: Supporting Excellence in Teacher Learning; Routledge: Abingdon, UK, 2016; pp. 114-123.

26. Mouraz, A.; Lopes, A.; Ferreira, J.M.; Pêgo, E.J.P. De Par Em Par Na Up: O Potencial Formativo Da Observação De Pares Multidisciplinar. Rev. Port. Investig. Educ. 2012, 12, 79-99. 
27. Leite, C.; Remião, F.; Huet, I.; Oliveira, J.F.; Teixeira, E.P. Discussão e validação da observação de pares multidisciplinares como modelo de formação no Ensino Superior (mesa redonda, olhares críticos). [Critical analysis of multi-disciplinary peer observation as a training model in Higher Education (round table, critical perspectives)]. SIPAR 2015, unpublished.

28. Pêgo, J.P.; Mouraz, A.; Salgado, A.; Freitas, E.A. De par em par interinstitucional: Uma experiência de formação pedagógica entre a U.Porto e o IPP. In Proceedings of the Porto ICRE19, Porto, Portugal, 17-19 July 2020; pp. 339-340.

29. Torres, A.C.; Lopes, A.; Valente, J.M.S.; Mouraz, A. What catches the eye in class observation? Observers' perspectives in a multidisciplinary peer observation of teaching program. Teach. High. Educ. 2017, 22, 822-838. [CrossRef]

30. Mouraz, A.; Rodrigues, S.; Guedes, M.; Carvalho, E.M. Contributos da observação de pares multidisciplinares nas práticas reflexivas de professores dos ensinos básico e secundário. Rev. Port. Investig. Educ. 2016, 16, 33-54.

31. Coutinho, C. Metodologia de Investigação em Ciências Sociais e Humanas; Leya: Lisbon, Portugal, 2014.

32. Hammersley-Fletcher, L.; Orsmond, E.P. Evaluating our peers: Is peer observation a meaningful process? Stud. High. Educ. 2004, 29, 489-503. [CrossRef]

33. Sanger, J. The Compleat Observer? A Field Research Guide to Observation; Routledge: London, UK, 2002.

34. Frank, R.H. Under the Influence: Putting Peer Pressure to Work; Princeton University Press: Princeton, NJ, USA, 2020 ; p. 299.

35. Dos Santos, L.M. Pre-service teachers' pedagogical development through the peer observation professional development programme. S. Afr. J. Educ. 2020, 40, 1-12. [CrossRef]

36. Dillon, H.; James, C.; Prestholdt, T.; Peterson, V.; Salomone, S.; Anctil, E. Development of a formative peer observation protocol for STEM faculty reflection. Assess. Eval. High. Educ. 2020, 45, 387-400. [CrossRef]

37. Akhmedova, F.; Rozikova, R. Enhancing language teachers' self-efficacy through peer observation in higher education. Конференции. [CrossRef]

38. Wingrove, D.A.; Hammersley-Fletcher, L.; Clarke, A. Chester, Leading developmental peer observation of teaching in higher education: Perspectives from Australia and England. Br. J. Educ. Stud. 2018, 66, 365-381. [CrossRef]

39. Nguyen, P.V.; Pham, H.T. Academics' perceptions of challenges of a peer observation of teaching pilot in a Confucian nation: The Vietnamese experience. Int. J. Acad. Dev. 2020. [CrossRef]

40. Paul, A.K. Enhancing Performance of Teachers through Peer Observation: A Critical Review for Implementation In Bangladeshi Colleges. Int. J. Asian Educ. 2021, 2, 64-78. [CrossRef]

41. Kocur, R.D. Collaborative Peer Observation of Teaching in Higher Education: Best Practices Review and Recommendations. Christ. Bus. Acad. Rev. 2021, 16, 135.

42. Bleiler-Baxter, S.K.; Hart, J.B.; Sister Cecilia Anne Wanner, O.P. Teaching TRIOs: Using Peer Observation to Initiate Department Change. PRIMUS 2020, 31, 550-564. [CrossRef]

43. Cosh, J. Peer Observation in Higher Education-A Reflective Approach. Innov. Educ. Train. Int. 1998, 35, 171-176. [CrossRef]

44. Donnelly, R. Perceived impact of peer observation of teaching in higher education. Int. J. Teach. Learn. High. Educ. 2007, 19, 117-129.

45. Klein, J.T. Interdisciplinarity: History, Theory, and Practice; Wayne State University Press: Detroit, NI, USA, 1990.

46. Spelt, E.J.H.; Biemans, H.J.A.; Tobi, H.; Luning, P.A.; Mulder, M. Teaching and Learning in Interdisciplinary Higher Education: A Systematic Review. Educ. Psychol. Rev. 2009, 21, 365-378. [CrossRef]

47. Hammersley-Fletcher, L.; Orsmond, P. Reflecting on reflective practices within peer observation. Stud. High. Educ. 2005, 30, 213-224. [CrossRef]

48. O'Keeffe, M.; Crehan, M.; Munro, M.; Logan, A.; Farrell, A.M.; Clarke, E.; Flood, M.; Ward, M.; Andreeva, T.; Van Egeraat, C.; et al. Exploring the role of peer observation of teaching in facilitating cross-institutional professional conversations about teaching and learning. Int. J. Acad. Dev. 2021, 26, 266-278. [CrossRef]

49. Wragg, E.C. An Introduction to Classroom Observation: Classic Edition; Taylor and Francis: New York, NY, USA, 2011.

50. Houssaye, J. Le Triangle Pédagogique; Peter Lang: Berne, Switzerland, 2014.

51. Postic, M.; Mialaret, E.G. Observation et Formation des Enseignants, 4th ed.; Mi. Presses Universitaires de France: Paris, France, 1992.

52. Cleaver, E.; Lintern, M.; McLinden, E.M. Teaching and Learning in Higher Education: Disciplinary Approaches to Educational Enquiry, 2nd ed.; SAGE: Southend Oaks, CA, USA, 2018.

53. Fong, C.J.; Warner, J.R.; Williams, K.M.; Schallert, D.L.; Chen, L.-H.; Williamson, Z.H.; Lin, S. Deconstructing constructive criticism: The nature of academic emotions associated with constructive, positive, and negative feedback. Learn. Individ. Differ. 2016, 49, 393-399. [CrossRef]

54. Jenkins, E.; D'Aoust, R.; Elias, S.; Han, H.R.; Sharps, P.; Alvarez, C. Faculty peer review of teaching taskforce: A quantitative descriptive research study for the peer review process. Nurse Educ. Today 2021, 106, 105055. [CrossRef]

55. Fletcher, J. Peer observation of teaching: A practical tool in higher education. J. Fac. Dev. 2017, 32, 51-64.

56. Carroll, C.; O'Loughlin, D. Peer observation of teaching: Enhancing academic engagement for new participants. Innov. Educ. Teach. Int. 2014, 51, 446-456. [CrossRef]

57. Bell, A.; Mladenovic, R. Situated learning, reflective practice and conceptual expansion: Effective peer observation for tutor development. Teach. High. Educ. 2014, 20, 24-36. [CrossRef]

58. Bozkurt, F. Teacher candidates' views on self and peer assessment as a tool for student development. Aust. J. Teach. Educ. 2020, 45, 47-60. [CrossRef] 
59. Noben, I.; Deinum, J.F.; Hofman, W.H.A. Quality of teaching in higher education: Reviewing teaching behaviour through classroom observations. Int. J. Acad. Dev. 2020, 1-14. [CrossRef]

60. Lee, M.F.; Lim, J.S.; Lai, C.S. Assessment of Teaching Practice Competency among In-Service Teacher Degree Program (PPG) in Universiti Tun Hussein Onn Malaysia. J. Tech. Educ. Train. 2020, 12, 181-188. [CrossRef]

61. OCDE. The Power of Observation: Learning from and with Teachers. OECD Education and Skills Today. Available online: https:/ / oecdedutoday.com/power-observation-learning-from-with-teachers/ (accessed on 16 November 2020).

62. Kaufman, T.E.; Grimm, E.E.D. The Transparent Teacher: Taking Charge of Your Instruction with Peer-Collected Classroom Data; Jossey-Bass: Hoboken, NJ, USA, 2013.

63. Ramon, M.R.R.; Mayol, B.D.L.I. El feedback entre iguales y su incidencia en el desarrollo profesional docente. Rev. Complut. Educ. 2021, 32, 371-382. [CrossRef]

64. De Lange, T.; Wittek, E.A.L. Analysing the constitution of trust in peer-based teacher mentoring groups-a sociocultural perspective. Teach. High. Educ. 2020, 1-15. [CrossRef] 